\title{
Practical Approach to Garbha Sambhavasamagri: A Case Study
}

\author{
Dr .Tomar Pravesh ${ }^{1}$, Dr. Garg Saloni ${ }^{2}$ \\ ${ }^{1}$ Professor, Dept. of Prasuti Tantra \& Stri Roga. Rishikul Campus, Haridwar, Uttrakhand Ayurveda \\ University ,Harrawala ,Dehradun (India) \\ ${ }^{2}$ PG Scholar, Dept. Of Prasuti Tantra \& Stri Roga. Rishikul Campus, Haridwar, Uttrakhand Ayurveda \\ University ,Harrawala ,Dehradun (India)
}

\begin{abstract}
:
The most widespread health issue in women today is fertility problems.In most cases the women do not know from where to start and they go for hormonal profiles, ovulation factors and many more costly and interventional Kapha Dosha Prakopainvestigations. In our principles of Ayurveda we consider the presence of four essential factors in a women called as Garbha Sambhavasamagrialong with unvitiated Doshas specially Vata Dosha to be able to conceive. Here is a case of infertiltiy viewed from ayurvedic eyes, occuring due to vitiated Doshas and abnormalities in Garbhasambhavasamgri. The patient was having Vata and which was leading to Artavkshaya(Ritukaal Dushti),Yoni Strava (Kshetra Dushti), Beej Granthi (Beej Dushti) and Aam Ras Dhatuformation (Ambu Dushti) and finally to infertilty in combination.Thus all four factors were affected in the present case. The women was given treatment based on the pathogenesis framed according to these four cardinal factors and she conceived after two months of treatment.
\end{abstract}

\section{Introduction:}

Infertility is "a disease of the reproductive system, defined by the failure to achieve a clinical pregnancy after 12 months or more of regular unprotected sexual intercourse." ${ }^{1}$.Infertility may have a single cause in one of the partners, or it could be the result of a combination of factors. Most people will have the strong desire to conceive a child at some point during their lifetime. Most couples (approximately 85\%) will achieve pregnancy within one year of trying. Only an additional $7 \%$ of couples will conceive in the second year. As a result, infertility has come to be defined as the inability to conceive within 12 months. However, there are various scenarios where one may be advised to seek help earlier. These include: irregular menses, family history of delayed conception, presence of any medical illness in any of the partner, age greater than 35 years, etc. ${ }^{2}$ The present available treatment of infertility is costly, less effective, have low success rates and also have the potential to affect negatively. In Ayurveda it is mentioned that in order to fulfill the achievement of Garbha, the four fertility factors i.e. Ritu, Kshetra, Ambu, Beejshould be adequate. ${ }^{3}$ Ritukaal is the most fertile period governed by kapha and pitta dosha. kshetrais healthy uterus and female genital tract which facilities the entry of sperm. Ambu represents the nutritional elements responsible for embryo implantation and fetal growth produced from diet. Beeja includes healthy ovum and sperm. All these factors are governed by presence of unvitiated Doshas. The line of treatment in Ayurveda is based on normalizing these four factors along with three Doshas.Here is presented a case of infertility seeking help early within 16 months of marriage. Considering the four factors of Garbhasambhava Samagri the Samprapti of the case is made and Samrapti Vighatan is done giving particular attention to each factor. The underlying conditions causing infertility are improved and the patient conceived within 2 months of treatment. 


\section{Case Study:}

A 21 years old female patient eager to conceivereported toPrasutitantra and Stree Roga outdoor department in Rishikul Campus of Uttrakhand Ayurveda University, Haridwar on 6 jan 2017. Her married life was 1.4 years. She was having chief complaint of scanty menses from 4 months and pain in lower abdomen, localized more to right lower quadrant. Pain had no relation with intercourse and was not that much severe to restrict her day to day activities.

She is also having associated white discharge per vaginum from 4 months along with lower backache. She was taking continuous allopathic treatment for conceiving from past 6 months but failed. No child was born in her family since 10 years. That is the reason she and her in laws are too eager for having her child within early months of her marriage. She visited Allopathic Hospital for her treatment. Lower abdominal USG $(11 / 12 / 2016)$ was done there and she was diagnosed for right ovarian cyst of about $(5.58 * 4.07 * 5.11 \mathrm{~cm})$ along with poly cystic appearance of left ovary (no. of follicles were more than 8).

She was advised hormonal treatment along with surgical removal of Ovarian Cyst. Patient was unwilling for the prescribed treatment. So she came to our hospital for Ayurvedic management.

Thorough interaction with the patient gives the following data:

The lady had menstrual cycle of 28 days. Duration of the flow was 2 days and she used 2 to 3 pads per day. The age of menarche was 13 yrs. She was living with her husband since her marriage. The marital relations were healthy. Husband's semen analysis report was absolutely normal. Any relevant past medical, surgical history, drug history and family history was not reported.

\section{Ashtvidhapariksha:}

Naadi (Pulse): Vataj

Malam(Faecal matter ) : Samanaya

Shabd (voice): Samnaya

Mutra (Urine): Samanya

Sparsh(skin texture): Ruksha

Jihva(tongue): Samanya

Drik (eyes): Samanya

Aakriti (body built): Krish

\section{Dashvidhapariksha :}

Prakriti (Physical and mental constitution): Pramana-Samanya

Vataj,Rajsik

Vikriti(Pathological condition): Vaat Kaphaj

Satmya(Homologation): Avara

Satva (Psychic constitution):Madhyama

Sara- (Dhatusaar-Perfectness of body tissue):

Aharashakti(Digestive capacity): Madhyama madhyama

Samhanana:Dhatubandhan- body compactnes Vyayamashakti(Capacity for exercise): Avar -samanya

\section{General Examination:}

General condition: fair

Blood pressure: $110 / 70 \mathrm{mmHg}$

Temperature: $98.4^{\circ} \mathrm{f}$

Pulse: 94\min

Pallor: +

Oedema: not any

Icterus: not any

Lymph nodes:not enlarged

Thyroid glands: not enlarged

Neck veins: not engorged 
Dr .Tomar Pravesh ${ }^{1}$, International Journal of Ayurvedic \& Herbal Medicine 7(4) July.-Aug. 2017 (2769-2773)

\section{Systemic examinations:}

CNS:Patient well oriented for time place and person and well conscious.

CVS: s1s2 heard no added sounds present.

$\mathrm{R} / \mathrm{S}$ : B/L chest clear, no added sounds present

Per abdomen: soft, non-tender abdomen.

\section{Gynaecological Examination:}

External examination:

Ringworm infection on inner part of thighs along with labia majora found.

$\mathrm{P} / \mathrm{S}$ : thick white discharge present,cervicalos nulliparous and cx red congested

$\mathrm{P} / \mathrm{V}$ : uterus nulliparous size, anteverted, a mass approx. $4 \mathrm{~cm}$ size felt in right fornix, left fornix clear.

\section{Investigations:}

Hemoglobin-13.2

TLC-4.6*10 $0^{3 /} \mathrm{UL}$

FBS-65.4 mg/dl

MCH-26.9 pq

HIV-NR

MCV-81.6 fl

HBsAg-NR

Anti HCV-NR

MPV- $14.5 \mathrm{fl}$

Serum TSH and prolactin were within normal limits.

HVS culture and sensitivity reports revealed gm-ve motile E.ColiSps

Wet smear- septate fungal hyphae present.

\section{Treatment Given:}

As per the reference given in our Ayurvedicclassics following treatment was prescribed for the period of two months:

- Shatpushpachurna 6 gm in two divided doses

- Shudh tankan bhasma $250 \mathrm{mg}$ in two divided doses

- Yograjguggulu $250 \mathrm{mg}$ 2BD

- Triflaguggulu $250 \mathrm{mg}$ 2BD

- A combination of Nimbachurna 3 gm+khadirachurna $3 \mathrm{gm}+$ Shudhgandhak $250 \mathrm{mg}+$ rasmanikya 120mg three times a day.

\section{Results:}

After 15 days of treatment patient got relieved in white discharge and itching per vaginum. Her ringworm rashes decreased in size. On continuing treatment the patient missed her period on 29 march 2017(LMP-29 feb 2017).

\section{Discussion:}

The main culprit Doshas involved in the present case is the Kapha and vat. Acharya sushruta laid down the importance of four factors in the conception and said that just as proper season, good field, enough supply of water and minerals and good seed are essential to produce a good crop, the Rutukala(a well-developed proliferative phase followed by ovulation), Kshetra(healthy reproductive system), Ambu (nutritional elements from Ahaar Rasa) and Beeja(ovum and sperm) are essential factors of conception. Imbalance of any of these features leads to infertility. In the present cause the Dushtiof all these four factors is manifesting as pcod, ovarian cyst and vaginal infection. According to Ayurvedapcos is caused by aggravated Kaphaleading to blockage to the flow of Vayu. The Prakopitvata and Kapha leads to Pit Dushtiand its 
Dr .Tomar Pravesh ${ }^{1}$, International Journal of Ayurvedic \& Herbal Medicine 7(4) July.-Aug. 2017 (2769-2773)

Kshaya. Formation of cysts and vaginal infections are the pathognomic effects of increased and stagnant Kaphadosha, Vatdosha And Aamras.

The possible pathogenesis in the present case is as follows:

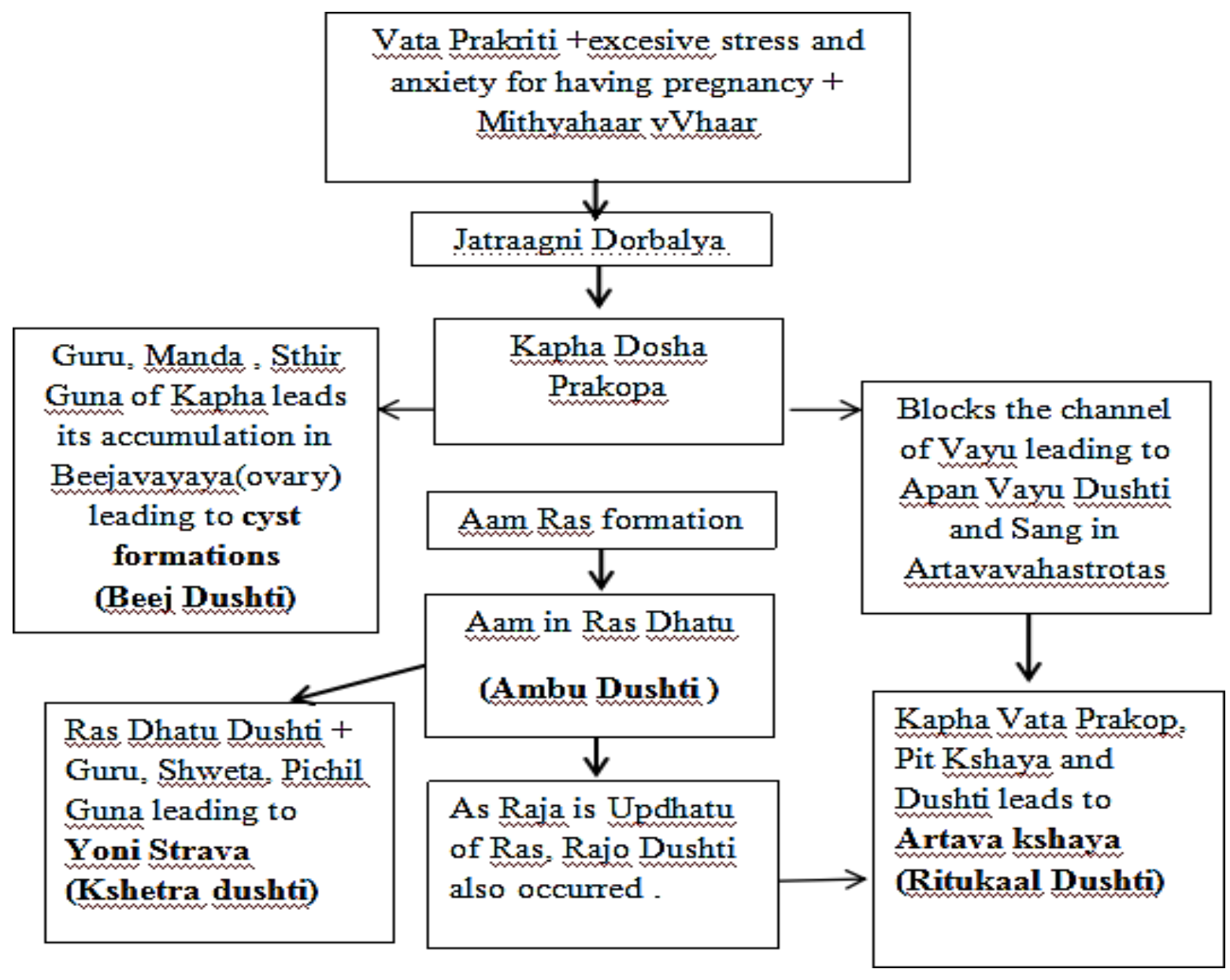

Mode of action of drugs used in the treatment:

Shatpusha is mainly Kapha-Vatashamaka, Vedanasthapaka, Shothahara, Deepaka, Pachaka, Krimihgnahara, Vata-Anulomaka. It contains phytoestrogens which have mixed estrogenic and antiestrogenic action, depending on target tissue. Acharya Kashypa highlighted the effect of Shatapushpa exclusively in many of gynaecological disorder such as ArtavaKshya or Anartava (amenorrhoea), VishphalaArtava, (without fruit means women not having child / can't conceive), Atyartava (menorrhagia) , Alpaartava (hypomenorrhoea), Kashtartava (dysmenorrhoea), Rajonirvrutti (menopause), Vandhya (infertility), Pushpaghni (PCOD/ PCOS), Yoni-Shushkata (dryness of vagina) and Daurbalya (weakness) ${ }^{4}$.

Tankan Bhasma is astringent and antiseptic; it promotes menstruation. It is regarded as Streepushpajanak(induces ovulation) by Rasacharyas. It alleviates Kapha and Vata and removes the obstruction in sub channels ${ }^{5}$.

Guggulu is having Katutikta Rasand Ushnaveerya. It is Strotoshodhak and have the ability to penetrate deeper cells by its Sukshmaguna. It clears the channel for flow of vaat which was obstructed by increased kapha ${ }^{6}$ Yograjguggulu is specially indicated for Vaatik disorders thus breaking down the pathogenesis from the root cause. Triflagugguluhave potent anti-inflammatory properties and induces cell death probably working on the cyst formation.

Nimba and khadira have katuvipaak, Tiktaras and kaphashamak properties. Due to TiktaRas they purify the Dushit Pitta Doshawhich was manifesting as the skin infection (ringworm).Nimba is potent 
Dr .Tomar Pravesh ${ }^{1}$, International Journal of Ayurvedic \& Herbal Medicine 7(4) July.-Aug. 2017 (2769-2773)

antimicrobial and decrease vaginal discharges by its Grahiguna. Rasmanikya is Vatkaphahar and exhibit potent antimicrobial and antifungal activities ${ }^{7}$.

Gandhak is Deepan, Pachan, Rasayan(immunomodulator) and beneficial for skin disorders. It clears off the Aam from Rasdhatu. Both Gandhak and Rasmanikya along with Khadir had worked in removing the ringworm infection from skin.

\section{Conclusion:}

The four factors essential for conception i.e Ritu ,Kshetra, Beej and Ambu are of uttermost importance. The manifestation of infertility in patients if understood and treated on the basis of these four cardinal points can lead to success even in the cases having multiple causes of failure to achieve pregnancy as in this case.

\section{References:}

1. WHO-ICMART glossary

2. http://www.who.int/reproductivehealth/topics/infertility/definitions/en/

3. Dr.Nirmala Joshi, Ayurvedic concept in Gynaecology (ChaukabhaSanskritaPratisthana, Delhi, 2006), Chapter VIII, Pages: 92-111.

4. Vridha Jivak. Kashyapa Samhita, Kalpa Sthana, Shatpushpa Shatavarikalpadhyaya, 5/8, Pandita Hemaraja Sharma, Commentator. $6^{\text {th }}$ Edition,Varanasi: Chaukambha Sanskrit Samsthana: 1998

5. Chunekar K. C., Bhavaprakasa Nighantu commentary, Haritakyadi varga, Chaukambha Bharati Academy Varanasi, Edition Reprint -2002; 170

6. Sharma, P.V. DravyagunaVignan, Vol. 2, published by ChaukhambhaBharati Academy, Varanasi. 2012. 55-56.

7. GyanendraPandey. DravyagunaVijnana, Part III, 2nd ed., published by ChaukhambaKrishnadas Academy, Varanasi. 2004. 428-431.

8. PremvatiTewari.AyurvediyaPrasutiTantraEvamStri-Roga. Part II, 2nd ed., published by ChaukhambaOrientalia, Varanasi. 2000. 167-170. 